\title{
Effect of Weed Management Practices in Chrysanthemum (Dendranthema grandiflora T.) under Chhattisgarh Plains Agro-climatic Condition
}

\author{
Gaurav Sharma $^{1 *}$, Alok Shrivastava ${ }^{2}$, D. S. Dhakre ${ }^{3}$ and D. P. Singh ${ }^{2}$
}

${ }^{1}$ Dept. of Horticulture, ${ }^{2}$ Dept. of Agricultural Statistics and Social Science, IGKV, Raipur, Chhattisgarh (492 012), India

${ }^{3}$ Dept. of EES, Institute of Agriculture, Visva-Bharati, Sriniketan, Birbhum, West Bengal (731 236), India

\section{Article History \\ Manuscript No. AR723 \\ Received in $17^{\text {th }}$ July, 2014 \\ Received in revised form $28^{\text {th }}$ August, 2014 \\ Accepted in final form $4^{\text {th }}$ September, 2014}

\section{Correspondence to}

*E-mail: gauravhort@gmail.com

\section{Keywords}

Chrysanthemum, hand weeding, herbicides, weeds, growth, flowering

\begin{abstract}
The present experiment was conducted at the Department of Horticulture, Indira Gandhi Krishi Vishwavidyalaya, Raipur (Chhattisgarh) during winter season to evaluate the effect of weed management practices on the growth and flowering of chrysanthemum. The experiment consisted of eleven treatments comprising of hand weeding, mulching, herbicides and unweeded check replicated three times in randomized block design. Maximum plant height, plant spread and number of branches plant ${ }^{-1}$ were recorded on application of pendimethalin (extra) @ $0.64 \mathrm{~kg} \mathrm{ha}^{-1}+$ one hand weeding at 40 DAT+pendimethalin (extra) @ $0.64 \mathrm{~kg} \mathrm{ha}^{-1}$ at 45 DAT followed by pendimethalin@ $1.0 \mathrm{~kg} \mathrm{ha}^{-1}+$ one hand weeding at 40 DAT which had at par effect. Highest average flower weight, number of flowers plant ${ }^{-1}$, flower diameter and earliest days to first bud appearance was obtained with pendimethalin (extra)@0.64 kg ha-1+one hand weeding at $40 \mathrm{DAT}+$ pendimethalin(extra)@0.64 $\mathrm{kg} \mathrm{ha}^{-1}$ at $45 \mathrm{DAT}$ which was having same effect as with pendimethalin@1.0 kg ha-1+one hand weeding at 40 DAT. The minimum dry matter and nitrogen uptake was noted under pendimethalin (extra) @ $0.64 \mathrm{~kg} \mathrm{ha}^{-1}+$ one hand weeding at $40 \mathrm{DAT}+$ pendimethalin (extra)@0.64 kg ha ${ }^{-1}$ at 45 DAT. Application of pendimethalin (extra)@ $0.64 \mathrm{~kg} \mathrm{ha}^{-1}+$ one hand weeding at $40 \mathrm{DAT}+$ pendimethalin (extra) @ $0.64 \mathrm{~kg} \mathrm{ha}^{-1}$ at $45 \mathrm{DAT}$ was found superior for parameters under observations, but it was found to have at par effect with pendimethalin (a) $1.0 \mathrm{~kg} \mathrm{ha}^{-1}+$ one hand weeding at 40 DAT.
\end{abstract}

\section{Introduction}

Chrysanthemum (Dendranthema grandiflora T.) is one of the most important flower crop grown commercially in India for cut and loose flowers and is also used for garden display.It belongs to family Asteraceae and is commonly called as the "Queen of the East".It ranks second to rose in the international flower trade. It is mostly used in our country for making garlands, veni, bracelets and in flower decoration and religious offerings. Chhattisgarh State, endowed with widely varying climatic conditions has tremendous potential for exploitation of commercial floriculture. The availability in range of colours and types of flowers adds to its value to be used for different purposes. Production of chrysanthemum in Chhattisgarh is estimated to be about $998 \mathrm{mt}$ with an area of about 276.06 ha (Chhattisgarh Horticulture, 2014). It is supposed to be among the top flower in terms of trade in Raipur market (Sharma, 2010). Much of the chrysanthemum flower demand and consumption is in the form of loose flowers for making garlands, bracelets, flower decoration and for worship.

However, one of the major constraints affecting chrysanthemum flower production is the cultural practices followed by the growers resulting in emergence of variety of weeds in the field. The presence of weeds in the fields and their impact on the crop production and environment has been well documented (Reza et al., 2006). Weeds compete with crop for nutrients, soil moisture, sun light and lead to reduction in the crop yield.Manual weeding is time consuming and costly due to requirement oflabour. Chemical weed control is one of the alternate methods of weed control in flower crops. But, soil persistence of herbicides can seriously affect the next crop in the rotation (Zaragoza, 2003). Efficient chemical weed control along with cultural practices has been reported to get targeted yield in flower crops (Kumar et al, 2010). Therefore, integrated approaches are considered as feasible option for weed management. However, not much work has been done on weed management in flower crops in Chhattisgarh. Therefore, 
field experiment was performed to test the efficacy of various herbicides alongwithmanual weedingfor higher yield in chrysanthemum.

\section{Materials and Methods}

The present experiment was conducted at the Department of Horticulture, Indira Gandhi Krishi Vishwavidyalaya, Raipur (C.G.) to evaluate the effect of weed management practices on growth and yield of chrysanthemum, weed dynamics and nutrient removal by weeds. Raipur, the place of investigation, is situated in the central part of Chhattisgarh at $21^{\circ} 16^{\prime} \mathrm{N}$ latitude, $81^{\circ} 36^{\prime} \mathrm{E}$ longitude and at an altitude of $289.56 \mathrm{~m}$ from mean sea level. Good quality rooted cuttings of chrysanthemum var. White Decorative was planted in the field having individual plot size of $1.5 \times 1.2 \mathrm{~m}$ with a spacing of $30 \times 30 \mathrm{~cm}$. All the recommended package of practice was followed.The experiment was laid out in a randomized block design with three replication having eleven treatments during rabi season of 2011-12. The treatments comprised ofhand weeding, paddy straw mulching, pre-transplanting treatments with alachlor 50\% EC @ $2.0 \mathrm{~kg} \mathrm{ha}^{-1}$, pendimethalin 30\% EC (a) $1.0 \mathrm{~kg} \mathrm{ha}^{-1}$, pendimethalin (extra) 37.8\% CS@0.64 kg $\mathrm{ha}^{-1}$, post-transplanting treatment with glyphosate 41\% SL @ $1.5 \mathrm{~kg} \mathrm{ha}^{-1}$ and unweeded check. Spraying was done by hand operated knap-sack sprayer with flat fan nozzle using water as carrier@500 L ha-1. The required quantity of herbicide was dissolved in measured quantity of water and sprayed uniformly over the plot. The blanket spray of alachlor, pendimethalin and pendimethalin (extra) and directed spray of glyphosate was made as per treatment.

\section{Results and Discussion}

In the experimental field, different types of weeds viz., broad leaf (Parthenium hysterophorus, Sonchusarvensis, Melilotusalba, Alternenthera triandra, Euphorbia hirta, Physalis minima, Convolvulus arvensis and Chenopodium album) and grasses (Cyperus iria and Cynodon dactylon) were found predominantly throughout the experimental period.

\subsection{Chrysanthemum crop growth and flowering parameters}

The treatments were found to have significant effect on the vegetative growth parameters and flowering attributes as compared to unweeded check (Table 1). Maximum plant height $(51.73 \mathrm{~cm})$, plant spread $(46.45 \mathrm{~cm})$ andnumber of branches plant ${ }^{-1}$ (21.33) was recorded on application of pendimethalin (extra)@ $0.64 \mathrm{~kg} \mathrm{ha}^{-1}+$ one hand weeding at $40 \mathrm{DAT}+$ pendimethalin (extra)@0.64 kg ha-1 at 45 DAT followed by pendimethalin @ $1.0 \mathrm{~kg} \mathrm{ha}^{-1}+$ one hand weeding at 40 DAT which, however, had at par effect.Effective weed control may have increased the capacity of the crop in utilizing soil moisture, light, nutrients and carbon dioxide in building new tissues that accounted for improving the vegetative growth (Mekki et al., 2010).Similarly, highest average flower weight (4.29 cm)andnumber of flowers plant ${ }^{-1}$ (57.99) and earliest days to first bud appearance (32.35) was obtained with pendimethalin (extra)@ $0.64 \mathrm{~kg} \mathrm{ha}^{-1}+$ one hand weeding at 40 DAT+pendimethalin (extra) @ $0.64 \mathrm{~kg} \mathrm{ha}^{-1}$ at 45 DAT followed by pendimethalin@1.0 kg ha-1+one hand weeding at 40 DAT

\begin{tabular}{|c|c|c|c|c|c|c|c|}
\hline Treatments & $\begin{array}{l}\text { Plant } \\
\text { ht. } \\
(\mathrm{cm})\end{array}$ & $\begin{array}{l}\text { Plant } \\
\text { spread } \\
(\mathrm{cm})\end{array}$ & $\begin{array}{l}\text { No. of } \\
\text { branches } \\
\text { plant }^{-1}\end{array}$ & $\begin{array}{c}\text { Days to } \\
1^{\text {st }} \text { bud } \\
\text { appearance }\end{array}$ & $\begin{array}{l}\text { Avg. } \\
\text { flower } \\
\text { wt. (g) }\end{array}$ & $\begin{array}{l}\text { Flower } \\
\text { diameter } \\
(\mathrm{cm})\end{array}$ & $\begin{array}{l}\text { No. of } \\
\text { flowers }^{-1} \\
\text { plant }^{-1}\end{array}$ \\
\hline Two hand weeding at 25 and 50 DAT & 44.77 & 31.67 & 10.66 & 50.54 & 2.46 & 5.85 & 38.54 \\
\hline Paddy straw mulch up to 60 DAT & 35.95 & 31.17 & 8.33 & 52.25 & 1.80 & 4.29 & 31.33 \\
\hline Alachlor 50\% EC@ @2.0 kg ha-1 & 38.23 & 30.65 & 9.66 & 50.85 & 1.83 & 4.52 & 32.66 \\
\hline Alachlor@2.0 kg ha-1 + one hand weeding at 40 DAT & 49.73 & 37.13 & 14.66 & 41.83 & 3.12 & 4.81 & 47.13 \\
\hline Pendimethalin@1.0 kg ha ${ }^{-1}$ & 38.26 & 30.70 & 10.41 & 52.06 & 2.30 & 3.58 & 34.17 \\
\hline Pendimethalin@1.0 kg ha ${ }^{-1}+$ one hand weeding at 40 DAT & 50.06 & 43.75 & 19.70 & 36.90 & 4.16 & 6.09 & 56.79 \\
\hline Glyphosate@ $1.5 \mathrm{~kg} \mathrm{ha}^{-1}$ at 30 and 60 DAT & 48.12 & 33.14 & 12.00 & 58.00 & 2.50 & 3.73 & 40.67 \\
\hline $\begin{array}{l}\text { Glyphosate } @ 1.5 \mathrm{~kg} \mathrm{ha}^{-1} \text { at } 30 \text { and } 60 \mathrm{DAT}+\text { one hand } \\
\text { weeding at } 15 \mathrm{DAT}\end{array}$ & 49.40 & 38.56 & 13.00 & 44.84 & 3.12 & 5.51 & 46.12 \\
\hline $\begin{array}{l}\text { Pendimethalin (extra)@0.64 kg ha }{ }^{-1}+\text { one hand } \\
\text { weeding at } 40 \text { DAT }\end{array}$ & 49.03 & 34.37 & 12.33 & 45.79 & 2.93 & 5.44 & 40.83 \\
\hline $\begin{array}{l}\text { Pendimethalin (extra)@0.64 kg ha } \mathrm{ha}^{-1}+\text { one hand } \\
\text { weeding at } 40 \text { DAT+Pendimethalin (extra) @ } 0.64 \\
\mathrm{~kg} \mathrm{ha}^{-1} \text { at } 45 \mathrm{DAT}\end{array}$ & 51.73 & 46.45 & 21.33 & 32.35 & 4.29 & 6.24 & 57.99 \\
\hline Unweeded check & 30.85 & 23.44 & 8.00 & 64.04 & 1.48 & 2.79 & 21.34 \\
\hline $\mathrm{SEm} \pm$ & 1.88 & 2.13 & 1.26 & 1.64 & 0.34 & 0.15 & 1.70 \\
\hline $\mathrm{CD}(p=0.05)$ & 5.55 & 6.28 & 3.73 & 4.85 & 1.00 & 0.44 & 5.02 \\
\hline
\end{tabular}


both having at par effect.The same trend was observed for flower diameter, with maximum flower diameter of $6.24 \mathrm{~cm}$ followed by $6.09 \mathrm{~cm}$ on application of pendimethalin (extra) (a) $0.64 \mathrm{~kg} \mathrm{ha}^{-1}+$ one hand weeding at $40 \mathrm{DAT}+$ pendimethalin (extra)@ $0.64 \mathrm{~kg} \mathrm{ha}^{-1}$ at $45 \mathrm{DAT}$ and treatment pendimethalin (a) $1.0 \mathrm{~kg} \mathrm{ha}^{-1}+$ one hand weeding at $40 \mathrm{DAT}$, respectively, both the treatments having same effectas with two hand weeding at 25 and 50 DAT. Higher yield in the weed management treatments may be attributed to higher chlorophyll content and photosynthetic rate due to effective control of weeds at critical crop-weed competition stages (Channappagoudar et al., 2006). Rameshkumar et al. (2012) also reported higher yield and better weed control under integrated weed management in tuberose.

\subsection{Effect of weed management practices on weeds and $N$ uptake}

The data presented in Table 2 reveals that the minimum weed countm $^{-2}$ (14.83) was recorded under pendimethalin (extra) @ $0.64 \mathrm{~kg} \mathrm{ha}^{-1}+$ one hand weeding at $40 \mathrm{DAT}+$ pendimethalin (extra) @ $0.64 \mathrm{~kg} \mathrm{ha}^{-1}$ at $45 \mathrm{DAT}$ and maximum (71.41) under unweeded check. Among the different weed species, the maximum weed count was recorded for Parthenium hysterophorus, Alternanthera triandra followed by Melilotus alba whereas, the minimum weed count was under Euphorbia hirta. With regard to fresh weight and dry matter of weeds, at 30 DAT, application of glyphosate @ $1.5 \mathrm{~kg} \mathrm{ha}^{-1}$ at 30 and $60 \mathrm{DAT}+$ one hand weeding at $15 \mathrm{DAT}$ was found to give least fresh and dry weight $\left(95.00 \mathrm{~g}^{-2}\right.$ and $10.44 \mathrm{~g}^{-2}$, respectively) which was having at par effect with paddy straw mulch up to 60 DAT, pendimethalin (extra)@ $0.64 \mathrm{~kg} \mathrm{ha}^{-1}+$ one hand weeding at $40 \mathrm{DAT}+$ pendimethalin (extra)@ $0.64 \mathrm{~kg} \mathrm{ha}^{-1}$ at 45 DAT, pendimethalin@ $1.0 \mathrm{~kg} \mathrm{ha}^{-1}+$ one hand weeding at 40 DAT and alachlor @ $2.0 \mathrm{~kg} \mathrm{ha}^{-1}+$ one hand weeding at 40 DAT. At 45 DAT, same trend was observed for fresh weight and dry matter of weeds, wherein pendimethalin (extra) @ 0.64 $\mathrm{kg} \mathrm{ha}^{-1}+$ one hand weeding at $40 \mathrm{DAT}+$ pendimethalin (extra) (a) $0.64 \mathrm{~kg} \mathrm{ha}^{-1}$ at $45 \mathrm{DAT}$ gave significantly minimum fresh weight (95.10 $\mathrm{g}^{-2}$ and $10.33 \mathrm{~g}^{-2}$, respectively) which was having similar effect with pendimethalin (extra)@0.64 kg ha ${ }^{-1}+$ one hand weeding at 40 DAT and two hand weeding at 25 and 50 DAT. At 60 DAT, pendimethalin (extra)@ $0.64 \mathrm{~kg} \mathrm{ha}^{-1}+$ one hand weeding at $40 \mathrm{DAT}+$ pendimethalin (extra)@ $0.64 \mathrm{~kg} \mathrm{ha}^{-1}$ at 45 DAT produced minimum fresh weight and dry matter of weeds ( $103.67 \mathrm{~g}^{-2}$ and $34.13 \mathrm{~g}^{-2}$, respectively) but pendimethalin @ $1.0 \mathrm{~kg} \mathrm{ha}^{-1}+$ one hand weeding at 40 DAT, alachlor @ $2.0 \mathrm{~kg}$ $\mathrm{ha}^{-1}+$ one hand weeding at 40 DAT and two hand weeding at 25 and $50 \mathrm{DAT}$, were also found to be equally effective. Whereas, at harvest, significantly minimum fresh weight and dry matter

\begin{tabular}{|c|c|c|c|c|c|c|c|c|c|c|}
\hline \multirow[t]{2}{*}{ Treatments } & \multirow{2}{*}{$\begin{array}{c}\text { Weed } \\
\text { count } \\
\text { at harvest } \\
\left(\text { no. } \mathrm{m}^{-2}\right)\end{array}$} & \multicolumn{4}{|c|}{ Fresh weight of weeds $\left(\mathrm{g}^{-2}\right)$} & \multicolumn{4}{|c|}{ Dry matter of weeds $\left(\mathrm{g}^{-2}\right)$} & \multirow{2}{*}{$\begin{array}{l}\mathrm{N} \text { uptake } \\
\text { by weeds } \\
\text { at harvest } \\
\left(\mathrm{Kg}^{-1}\right)\end{array}$} \\
\hline & & $\begin{array}{c}30 \\
\text { DAT }\end{array}$ & $\begin{array}{c}45 \\
\text { DAT }\end{array}$ & $\begin{array}{c}60 \\
\text { DAT }\end{array}$ & $\begin{array}{c}\text { At } \\
\text { harvest }\end{array}$ & $\begin{array}{c}30 \\
\text { DAT }\end{array}$ & $\begin{array}{c}45 \\
\text { DAT }\end{array}$ & $\begin{array}{c}60 \\
\text { DAT }\end{array}$ & $\begin{array}{c}\text { At } \\
\text { harvest }\end{array}$ & \\
\hline Two hand weeding at 25 and 50 DAT & 28 & 118.33 & 101.73 & 120.67 & 89.16 & 24.02 & 12.18 & 38.00 & 7.06 & 3.21 \\
\hline Paddy straw mulch up to 60 DAT & 40 & 96.33 & 148.80 & 331.00 & 101.73 & 10.79 & 20.33 & 65.63 & 10.24 & 7.52 \\
\hline Alachlor@ $2.0 \mathrm{~kg} \mathrm{ha}^{-1}$ & 36 & 111.67 & 200.07 & 233.93 & 97.48 & 18.74 & 36.50 & 59.50 & 7.56 & 10.11 \\
\hline $\begin{array}{l}\text { Alachlor @ } 2.0 \mathrm{~kg} \mathrm{ha}^{-1}+\text { one hand } \\
\text { weeding at } 40 \text { DAT }\end{array}$ & 20 & 100.67 & 170.27 & 119.67 & 61.13 & 12.45 & 24.01 & 35.50 & 4.10 & 4.00 \\
\hline Pendimethalin@1.0 kg ha ${ }^{-1}$ & 33 & 107.00 & 180.30 & 222.67 & 94.20 & 14.23 & 26.20 & 50.13 & 6.97 & 5.01 \\
\hline $\begin{array}{l}\text { Pendimethalin@1.0 } \mathrm{kg} \mathrm{ha}^{-1}+\text { one } \\
\text { hand weeding at } 40 \text { DAT }\end{array}$ & 17 & 99.67 & 113.50 & 111.50 & 60.33 & 11.67 & 22.05 & 37.57 & 3.83 & 3.62 \\
\hline $\begin{array}{l}\text { Glyphosate @ } 1.5 \mathrm{~kg} \mathrm{ha}^{-1} \text { at } 30 \\
\text { and } 60 \text { DAT }\end{array}$ & 22 & 115.17 & 105.33 & 160.80 & 77.83 & 23.02 & 13.49 & 43.23 & 6.70 & 5.98 \\
\hline $\begin{array}{l}\text { Glyphosate @ } 1.5 \mathrm{~kg} \mathrm{ha}^{-1} \text { at } 30 \text { and } 60 \\
\text { DAT+one hand weeding at } 15 \text { DAT }\end{array}$ & 19 & 95.00 & 110.27 & 124.17 & 61.50 & 10.44 & 14.17 & 38.67 & 4.13 & 3.93 \\
\hline $\begin{array}{l}\text { Pendimethalin (extra) @ } 0.64 \mathrm{~kg} \text { ha- } \\
{ }^{1}+\text { one hand weeding at } 40 \text { DAT }\end{array}$ & 22 & 105.17 & 100.13 & 130.33 & 66.50 & 13.63 & 11.04 & 40.67 & 5.25 & 5.00 \\
\hline $\begin{array}{l}\text { Pendimethalin (extra)@0 } 0.64 \\
\mathrm{~kg} \mathrm{ha}^{-1}+\text { one hand weeding at } 40 \\
\text { DAT+Pendimethalin (extra) @ } \\
0.64 \mathrm{~kg} \mathrm{ha}^{-1} \text { at } 45 \text { DAT }\end{array}$ & 15 & 96.83 & 95.10 & 103.67 & 59.33 & 11.52 & 10.33 & 34.10 & 3.43 & 2.33 \\
\hline Unweeded check & 71 & 128.33 & 401.87 & 442.17 & 111.44 & 25.83 & 86.77 & 106.45 & 15.25 & 13.98 \\
\hline $\operatorname{SEm} \pm$ & - & 2.00 & 3.45 & 9.86 & 0.71 & 0.70 & 1.01 & 1.40 & 0.39 & - \\
\hline $\mathrm{CD}(p=0.05)$ & - & 5.94 & 10.6 & 29.09 & 2.11 & 2.10 & 3.02 & 4.13 & 1.17 & \\
\hline
\end{tabular}


of weeds (59.33 $\mathrm{g}^{-2}$ and $3.43 \mathrm{~g}^{-2}$, respectively) was obtained under pendimethalin (extra) @ $0.64 \mathrm{~kg} \mathrm{ha}^{-1}+$ one hand weeding at 40 DAT+pendimethalin (extra) @ $0.64 \mathrm{~kg} \mathrm{ha}^{-1}$ at 45 DAT whose effect was statistically similar with pendimethalin @ $1.0 \mathrm{~kg} \mathrm{ha}^{-1}+$ one hand weeding at 40 DAT and alachlor @ 2.0 $\mathrm{kg} \mathrm{ha}^{-1}+$ one hand weeding at 40 DAT. However, glyphosate (a) $1.5 \mathrm{~kg} \mathrm{ha}^{-1}$ at 30 and $60 \mathrm{DAT}+$ one hand weeding at $15 \mathrm{DAT}$ was also having at par effect with respect to dry matter of weeds. This may be attributed to better control of weeds thereby lower weed population and suppression of weed growth which might have resulted in lower accumulation of dry matter of weeds (Biradar et al., 1999). Similar results were obtained by Sharma and Jain (2002), who reported that weed management treatments decreased the weed population and weed weight and consequently increased the weed control efficiency. Whereas, Lhungdim et al. (2013) reported that among sole applications, pendimethalin was able to significantly suppress broadleaved weeds in lentil.The results are in line with the findings of Raghav et al. (1995) and Kunti et al. (2012).

Weed management practices adopted drastically reduced nitrogen removal by weeds as compared to unweeded check. Maximum nitrogen up take by weeds $\left(13.98 \mathrm{~kg} \mathrm{~N} \mathrm{ha}^{-1}\right)$ was observed under unweeded check. Whereas, minimum removal (2.33 $\mathrm{kg} \mathrm{N} \mathrm{ha}^{-1}$ ) was registered under pendimethalin (extra) (a) $0.64 \mathrm{~kg} \mathrm{ha}^{-1}+$ one hand weeding at $40 \mathrm{DAT}+$ pendimethalin (extra)@0.64 kg ha-1 at 45 DAT. Under unweeded check, weeds were allowed to grow without any management and thus might have removed higher amount of nitrogen (Saraf, 2007). Mandira and George (2003) also reported that nutrient removal by weeds was highest under the unweeded check. Therefore, it can be inferred from the present findings that though, the application of pendimethalin (extra) @ $0.64 \mathrm{~kg} \mathrm{ha}^{-1}+$ one hand weeding at $40 \mathrm{DAT}+$ pendimethalin (extra)@ $0.64 \mathrm{~kg} \mathrm{ha}^{-1}$ at 45 DAT was found superior for parameters under observation but it was found to have at par effect with pendimethalin @ $1.0 \mathrm{~kg} \mathrm{ha}^{-1}+$ one hand weeding at 40 DAT.

\section{Conclusion}

Application of pendimethalin (extra)@ $0.64 \mathrm{~kg} \mathrm{ha}^{-1}+$ one hand weeding at $40 \mathrm{DAT}+$ pendimethalin (extra) @ $0.64 \mathrm{~kg}$ $\mathrm{ha}^{-1}$ at 45 DAT was found to suppress the weeds and result in higher growth and flowering parameters in chrysanthemum. However, its effect was found to be statistically similar with pendimethalin@1.0 kg ha ${ }^{-1}+$ one hand weeding at 40 DAT.

\section{References}

Biradar, S.A., Agasimani, C.A., Yenagi, B.S., 1999. Integrated weed management in chilli (Capsicum annum L.) under northern transition tract of Karnataka. World Weeds 6(1), 53-59.

Channappagoudar, B.S., Birada, N.R., 2007. Physiological studies on weed control efficiency in direct sown onion. Karnataka Journal of Agricultural Science 20(2), 375-376.

Chhattisgarh Horticulture, 2014. Statistics: At a glance. Directorate of Horticulture, Raipur,

Government of Chhattisgarh.Availablefrom www. cghorticulture.gov.in/statistics.htm.

Kumar, A., Sharma, B.C., Kumar, R., Sharma, P.K., Wazir, V., 2010. Integrated weed management in marigold under irrigated sub-tropical conditions of Jammu \& Kashmir. Indian Journal of Weed Science 42(1\&2), 10-13.

Kunti, Sharma, G., Singh, A.P., 2012. Weed management practices on growth and yield of winter season brinjal under Chhattisgarh plain conditions. Indian Journal of Weed Science 44(1), 18-20.

Lhungdim, J., Singh, Y., Singh, R.P., 2013. Integration of chemical and manual weed management on weed density, yield and production economics of Lentil (Lens culinaris Medikus).International Journal of Bio-resource and Stress Management 4(4), 593-598.

Mandira, C., George, S., 2003. Effect of weed management practices on the nutrient removal by weeds in brinjal(Solanum melongena L.). New Agriculturist 14(1/2), 27-31.

Mekki, B.B., Faida, A.A., Kowthar, G., 2010. Effect of weed control treatments on yield and seed quality of some Canola cultivars and associated weeds in newly reclaimed sandy soils. American-Eurasian Journal of Agriculture and Environment Science 7(2), 202-209.

Raghav, M., 1995. Weed management studies in kharif brinjal. Vegetable Science 22(2), 90-91.

Rameshkumar, S., Geetha, J.T., Sathappan, C.T., Sureshkumar, S.M., Kathiresan, R.M., 2012. Integrated weed management in flower crops involving goat grazing and polyethylene mulching. Pakistan Journal of Weed Science Research 18, 855-862.

Reza, H., Chamanadad, M., Tulikov, A.M., Baghestani, M.A., 2006. Effect of long-term fertilizer application and crop rotation on the infestation of fields by weeds. Pakistan Journal of Weed Science Research 12(3), 221-234.

Saraf, R.K., 2007. Herbicidal weed control in kharif onion. The Asian Journal of Horticulture 2(1), 1-5.

Sharma, G., 2010. Assessment of flower trade in Raipur city of Chhattisgarh state: status and prospects. In: National Symposium on Conservation Horticulture. Dehradun, India, 268.

Sharma, O.L., Jain, N.K., 2002. Effect of herbicides on weed dynamics and seed yield of Indian mustard (Brassica juncea). Indian Journal of Agricultural Sciences 72(6), 322-324.

Zaragoza, C., 2003. Weed management in vegetables. In: R. Labrada (Ed.), Weed management for developing countries. FAO, Rome, 120 (Add.1), 145-157. 